\title{
Evaluation of groundwater quality and its impact on human health: a case study from Chotanagpur plateau fringe region in India
}

\author{
Baisakhi Chakraborty ${ }^{1}$. Sambhunath Roy ${ }^{1}$. Biswajit Bera ${ }^{2} \cdot$ Partha Pratim Adhikary ${ }^{3}$. Sumana Bhattacharjee ${ }^{4}$. \\ Debashish Sengupta ${ }^{5} \cdot$ Pravat Kumar Shit $^{1}$
}

Received: 10 September 2021 / Accepted: 15 November 2021 / Published online: 7 February 2022

(c) The Author(s) 2021

\begin{abstract}
Groundwater is a vital and purest form of natural resource. In the recent years, various anthropogenic causes threat its natural quality. Therefore, its suitability for drinking, irrigation and other purposes make doubtful conditions of human well-being, especially in developing countries. In this present study, groundwater quality was evaluated for drinking, irrigation and human health hazard purposes particularly in Chotanagpur plateau fringe of India. In total, 58 water samples were collected from different locations in pre-monsoon (February-March 2020) and post-monsoon (October-November 2020) seasons to delineate seasonal variation of groundwater quality according to as reported by WHO (WHO guidelines for drinking-water quality, World Health Organization, Geneva, 2011) guidelines. Groundwater Quality Index (GWQI) and Heavy metal Pollution Index (HPI) have been applied to assess the suitability of drinking purposes. Irrigation parameters (SAR, SSP, MAR, PI, KR) showed the significant deterioration of water quality in pre-monsoon than post-monsoon period. Major cations (such as sodium, calcium) and major anions (such as bicarbonate, nitrate and fluoride) exceeded their standard limit in both the seasons. Non-carcinogenic health risk is found due to heavy metal contamination through drinking water. The health risk index was higher for children in comparison with adults. This research finding can definitely help to planners and administrators for immediate decision making regarding public health (for groundwater quality improvement).
\end{abstract}

Keywords Groundwater quality (GWQ) · Groundwater pollution (GWP) · Heavy metal pollution index (HPI) · Human health risk (HHR) · Spatial mapping

Baisakhi Chakraborty
bchakraborty201595@gmail.com
Sambhunath Roy
sambhuroynath95@gmail.com
Biswajit Bera
biswajitbera007@gmail.com
Partha Pratim Adhikary
ppadhikary@gmail.com
Sumana Bhattacharjee
sumana.aarohi@gmail.com
Debashish Sengupta
dsgg@gg.iitkgp.ac.in
Pravat Kumar Shit
pravatgeo2007@gmail.com

Baisakhi Chakraborty

bchakraborty201595@gmail.com

Sambhunath Roy

Biswajit Bera

biswajitbera007@gmail.com

Partha Pratim Adhikary

Sumana Bhattacharjee

sumana.aarohi@gmail.com

Debashish Sengupta

Pravat Kumar Shit

pravatgeo2007@gmaing o
1 PG Department of Geography, Raja N. L. Khan Women's College (Autonomous), Gope Palace, Midnapore, West Bengal 721102, India

2 Department of Geography, Sidho Kanho Birsha University, Purulia, India

3 ICAR Indian Institute Water Management, Bhubaneswar, Odisha 751023, India

4 Department of Geography, University of Calcutta, 35, Ballygunge Circular Road, Ballygunge, Kolkata 700019, India

5 Department of Geology and Geophysics, Indian Institute of Technology (IIT), Kharagpur, West Bengal 721302, India 


\section{Introduction}

In the pre-industrial era, surface and subsurface water was considered as safe for drinking and human welfare. No such significant negative impression of water quality and related environmental hazard was found during that period. After industrial revolution in eighteenth century, uncontrolled development of anthropogenic activities leads water resources vulnerable through contamination of various pollutants (Al-Sudani 2019). Population explosion, over-exploitation and inappropriate usages of chemicals in different sectors continuously threat the precious natural resource. Once groundwater (GW) was purest form of water resource, but today, the quality is being deteriorated day by day and exposed to human health risk due to improper knowledge and management. Generally, quality of GW depends on physiochemical properties of aquifer and its composition. This state is controlled by the properties of soil and rocks of aquifer media (Acheampong and Hess 1998; Foster et al. 2000; Raji and Alagbe 1997). Different hydrogeochemical process determines different physicochemical characteristics of GW particularly in the zone of saturation (Islam et al. 2017a; Ahmed et al. 2020; Bhuiyan et al. 2016). Chemical components of industrial, agricultural, urban sewage, mining extracts are the main causes of high pollutant contamination in GW (Amirabdollahian and Datta 2013; Carpenter et al. 1998; Simeonov et al. 2003). Many previous studies were conducted on assessment of GW pollution in different parts of the world and find significant deterioration in water quality for drinking and irrigation purposes in recent times (Al- Futaisi et al. 2007; Pritchard et al. 2008; Jalali 2006; Bhunia et al. 2018). Groundwater unsuitability for drinking and irrigation purposes in Volta River basin of Ghana was analyzed by Kaka et al. 2011. Jennings et al. (1997) showed the increased level of nitrates in GW and its negative impact on human health. Al- Sudani (2003) assessed GW quality of Debagah basin in Iran and found higher contamination of anions, nitrates and salinity from agricultural source. Kong et al (2004) analyzed GW quality of agricultural field in Hebei and Shandong, and it indicated the deterioration of quality of groundwater due to high mixing of pesticides in GW. Rapid water quality deterioration and unsuitability for drinking or irrigation is a burning issue in most of the developing countries. Rapid population explosion, high yielding varieties of crop cultivation, excessive application of chemical fertilizers, pesticides, fungicides and herbicides, urban and industrial effluents and improper management are the principal cases of groundwater pollution particularly in developing countries (Nagaraju et al. 2018; Shaji et al. 2018). Several studies reported that the magnitude of GWP has been amplified by both natural and anthropogenic sources in Bangladesh (Hasan et al. 2019; Kabir et al. 2021; Islam et al. 2020). In India, GW plays a significant role particularly in domestic and irrigation sectors. It has been reported that GW uses nearly $80 \%$ for domestic use in rural areas and approximately $50 \%$ in urban areas (Kundu and Nag 2018). In India, around 50\% of agricultural lands depend on groundwater irrigation (Central Water Commission 2006). But in the recent years, this most valuable resource is going to vulnerable for human consumption. Many studies were conducted in this approach. Water quality of coastal aquifers in Tamil Nadu state, India, was assessed for its hydrochemical condition and suitability of human consumption (Chandrasekar et al. 2014). Similarly, groundwater quality of an agricultural region of Uttar Pradesh, India, was assessed for drinking suitability (Ashwini and Abhay 2014). Degree of GWP in rural areas of Telangana state was showed that major cations and anions along with their permissible limit were exceeded due to high activity of geogenic condition and anthropogenic contamination (Subba Rao et al. 2018). Gautam et al. 2015 analyzed GWQ of Subarnarekha River basin of Chotonagpur region and explained large-scale release of ions through weathering and agricultural practices. Satish Kumar et al. (2016) assessed GWQ of hard rock aquifer of Pudunagaram, Palakkad district of Kerala, and indicated most of water samples were suitable for drinking and irrigation purposes, though some samples were higher than their standard limit due to anthropogenic contribution. Groundwater quality (GWQ) of Bankura I and Bankura II blocks of West Bengal indicated moderately suitable for drinking and irrigation purposes except some places (Nag and Das 2017). The most warning problem related to GW pollution is its adverse impact on human health in developing countries. Regular intake of toxic elements (heavy metals) accelerates chronic non-carcinogenic or carcinogenic diseases of humans (Tasneem et al. 2021; Ahmed et al. 2021; Mridul et al. 2020). In developing countries, poor drinking water and unhealthy sanitary system are responsible for $80 \%$ water borne diseases reported by UNESCO 2007. Health risk assessment on an agricultural region of Nanganur, South India, showed higher health risk (non-carcinogenic) of children than adult by intake of nitrate in drinking water (Adimalla and Qian, 2019). Adimalla and Wu (2018) assessed noncarcinogenic health risk of central Telangana and showed that infant was most exposed to health risk by ingestion of nitrate and fluoride in drinking water. Therefore, it is highly required to assess the GWQ for drinking, irrigation and human health particularly in developing countries and it needs for implementation of sustainable development practice (Islam et al. 2020). As quality of groundwater depends on numerous physiochemical parameters, it is 
quite hard to deal with large dataset. In this case, it is revealed that Water Quality Index (WQI) is the most suitable technique to evaluate water quality standard. In this process, different weightage values are assigned for different parameters according to their relative importance on overall groundwater quality (Singh et al. 2018; Shahid et al. 2014). WQI is an appropriate technique to determine GWQ depending on physiochemical parameters for drinking purpose. Therefore, Heavy Metal Pollution Index (HPI) is necessary to assess drinking water quality on the basis of toxic metal contamination (Edet and Offiong 2002; Sultana et al. 2016; Rikta et al. 2016; Ojekunle et al. 2016; Karunanidhi et al. 2020). Many relevant studies on groundwater quality (GWQ) of irrigation suitability has been assessed by different indices such as sodium adsorption ratio (SAR), permeability index (PI), soluble sodium percentage (SSP), Kelly's ratio (KR) and magnesium adsorption ratio (MAR) and along with using different ionic concentration in GW (Ashraf and Afzal 2011; Kundu and Nag 2018; Chakraborty et al. 2021a, b, c). In the recent years, modern scientific techniques are applied with the combination of traditional methods particularly in applied research. Application of remote sensing and spatial zonation by GIS techniques easily helped to identify the pollution pockets of $\mathrm{GW}$ and associated health risk (HR) (Taheri et al. 2015; Singh et al. 2015; Thapa et al. 2017).

Our present study area is located in Santuri block of Purulia district of West Bengal. It is situated at fringe area of Chotanagpur plateau, and geomorphologically, it is an undulating terrain with Precambrian granite gneiss residual hillocks. Some medium-sized iron-based industries and secondary activities have been grown in the recent decades. High demand of groundwater for drinking and agricultural purposes emerges severe water crisis in this area day by day. Prior study on groundwater quality of its adjacent block Neturia showed that anthropogenic sources are responsible for groundwater contamination along with some natural factors and study also identified magnitude of health hazard through consuming high amount of iron and fluoride in drinking water (Chakraborty et al. 2021a, b, c). But no such previous study was found on groundwater quality with an integrated approach in any part of the country, especially on eastern fringe of Chotanagpur region. Therefore, the principal objective of this study is to i) evaluate hydrochemical characteristics of groundwater and ii) assess the GWQ suitability for drinking, irrigation and non-carcinogenic health risk of humans using GIS techniques and research also highlights some sustainable remedial measures for regional planners and local people.

\section{Materials and methods}

\section{Study area}

Santuri Block is situated in the northeastern part of Purulia district within geographical extension $23^{\circ} 27^{\prime} 43^{\prime \prime}$ $\mathrm{N} / 86^{\circ} 45^{\prime} 50^{\prime \prime} \mathrm{N}$ to $23^{\circ} 39^{\prime} 35^{\prime \prime} \mathrm{N} / 86^{\circ} 54^{\prime} 33^{\prime \prime} \mathrm{N}$ with 179.69 $\mathrm{km}^{2}$ area (Fig. 1). Damodar River is the northern boundary of Santuri Block as well as Purulia district. Geological or more specifically lithology of this block is composed by Gondowana crystalline rock formation, granite gneiss, mica schist. Meta basic rocks are also found in some places along with lineaments. Geomorphologically, it is an undulating plateau with plain, and generally, slope of the land is toward east. Annual temperature is varying between 4 and $45^{\circ} \mathrm{C}$. Annual rainfall is recorded within the range $1100-1400 \mathrm{~mm}$. Topsoil is characterized by weathered laterites along with sandy residue. Agriculture is mostly being practiced by the river water (Damodar) and dam. Groundwater is the main source of drinking water in this block. Pit well, dug well, bore well, etc. are common structural modes of extraction from groundwater aquifer.

\section{Sample collection and procedures}

Groundwater samples were collected from 29 bore wells of different location in pre-monsoon (February-March) and post-monsoon (October-November) of the year 2020 (Fig. 1). Sampling locations were recorded by portable GPS instrument (GARMIN GPS map $78 \mathrm{~s}$ ). Each bottle of $500 \mathrm{ml}$ was deionized by 1: 1 hydrochloric acid and thoroughly cleaned by sampling water of respective site. After sampling, all bottles were labeled accordingly and sealed with plastic coat for prevention of evaporation and carried to laboratory within $24 \mathrm{~h}$. Similarly, $\mathrm{pH}$ and EC were measured by their portable meters in situ (Hanna). TDS was measured by multiplying EC with 0.64 (Hem 1991). All chemical parameters were analyzed by the recommended method of American Public Health Association (APHA 2012). TH and cations as $\mathrm{Ca}^{2+}$ and $\mathrm{Mg}^{2+}$ were measured by EDTA titration method $(0.05 \mathrm{~N}$ and $0.01 \mathrm{~N}$, respectively). $\mathrm{Na}^{2+}$ and $\mathrm{K}^{+}$were measured by flame photometer method. Anions as $\mathrm{Cl}^{-}$and $\mathrm{HcO}_{3}{ }^{-}$were obtained by volumetric method. $\mathrm{So}_{4}{ }^{-}, \mathrm{No}_{3}{ }^{-}$and $\mathrm{F}^{-}$were estimated by spectrophotometric method (Chakraborty et al. 2021a, $\mathrm{b}, \mathrm{c}$ ). All concentrations were expressed in $\mathrm{mg} / \mathrm{l}$ except $\mathrm{pH}$ and EC. Heavy metals like iron, chromium, manganese, cadmium, zinc, copper, lead and nickel were estimated by anodic stripping voltammetry (VA 797, Switzerland) using three types of pulse analyzer. Voltametric pulse peak was 

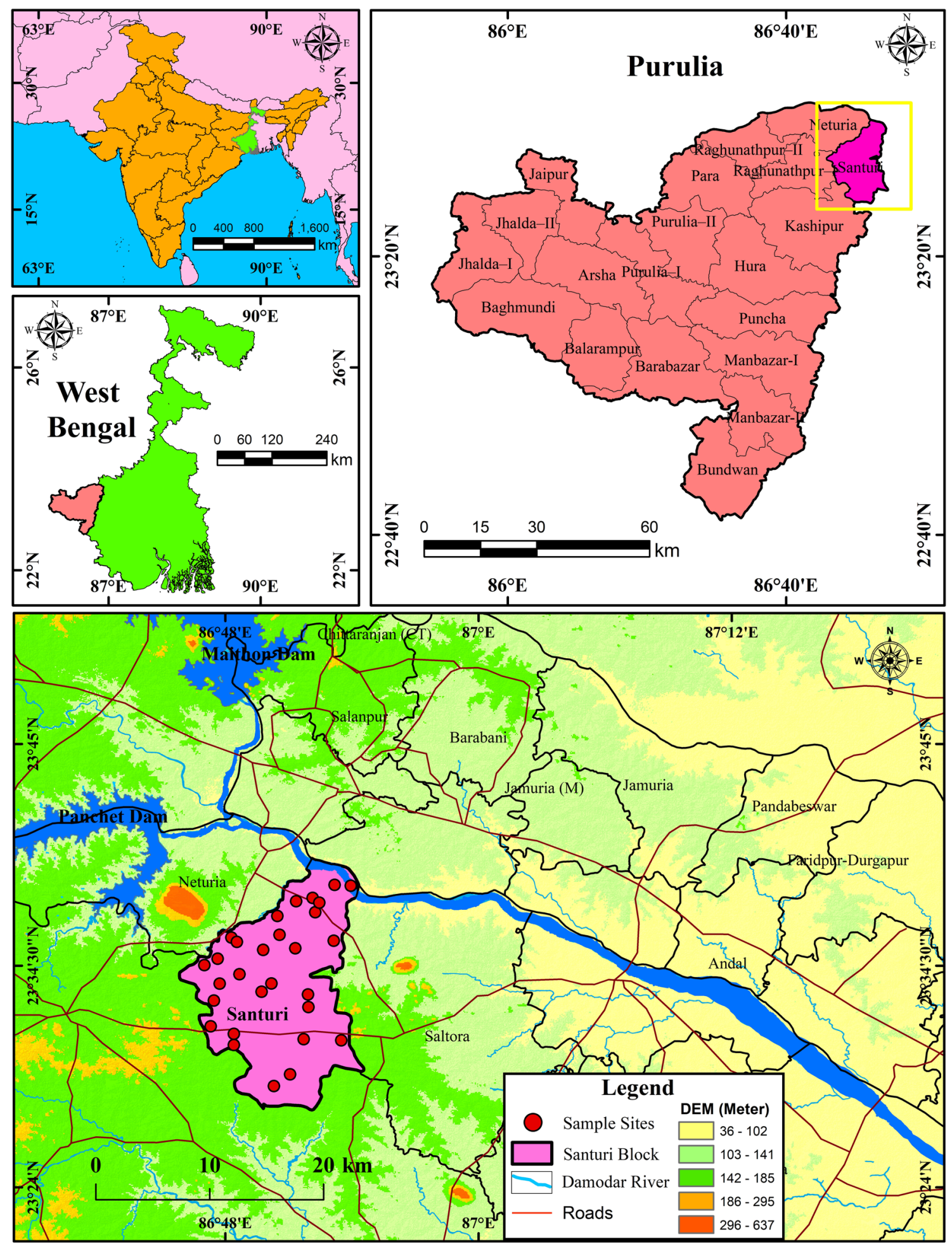

Fig. 1 Location of the study area and sampling sites

recorded in a window computer (Chakraborty et al. 2020). All heavy metals are expressed in $\mu \mathrm{g} / \mathrm{l}$.

Ionic balance was conducted for each groundwater samples in quality assurance of chemical analysis (Huh et al.
1998). In this process, ionic concentration of all chemicals was converted into meq/l and estimated ionic balance by the following equation 


$$
\begin{aligned}
\text { Ionic balance }= & {\left[100 \times\left(\sum \text { Cation }-\sum \text { Anion }\right)\right] / } \\
& {\left[\sum \text { Cation }+\sum \text { Anion }\right] }
\end{aligned}
$$

\section{Groundwater quality index (GWQI)}

Groundwater quality index or GWQI can easily determine overall groundwater quality on the basis of physicochemical parameters of water sample for drinking. GWQI has been conducted using the following formula (Vasanthavigar et al. 2010; Islam et al. 2017b).

$\mathrm{GWQI}=\sum S I=\sum(W i \times Q i)=\sum\left[\left(\frac{w_{i}}{\sum_{n}^{i=1} w_{i}}\right) \times\left(\frac{C_{i}}{S_{i}} \times 100\right)\right]$

Variables, their assigned weight and standard values of parameters for GWQI calculation are given in Table 1 (Vasanthavigar et al. 2010; Chakraborty et al. 2021a, b, c).

Table 1 Parameters, their weights, relative weights and standard values of GWQI assessment (Vasanthavigar et al. 2010; Chakraborty

\begin{tabular}{|c|c|c|c|c|}
\hline Parameters & Weight $\left(\mathrm{w}_{\mathrm{i}}\right)$ & $\begin{array}{l}\text { Relative } \\
\text { weight } \\
\left(\mathrm{W}_{\mathrm{i}}\right)\end{array}$ & $\begin{array}{l}\text { Standard } \\
\text { value }\left(\mathrm{S}_{\mathrm{i}}\right) \\
\text { WHO } \\
(2011)\end{array}$ & $\begin{array}{l}\text { Standard } \\
\text { value }\left(S_{\mathrm{i}}\right) \text { BIS } \\
(2012)\end{array}$ \\
\hline $\mathrm{pH}$ & 4 & 0.066 & $6.5-9.2$ & $6.5-8.5$ \\
\hline $\mathrm{EC}(\mu \mathrm{s} / \mathrm{cm})$ & 2 & 0.033 & 1500 & - \\
\hline TDS (mg/l) & 5 & 0.083 & 1000 & 500 \\
\hline TH (mg/l) & 2 & 0.033 & - & 300 \\
\hline $\mathrm{Na}^{2+}(\mathrm{mg} / \mathrm{l})$ & 4 & 0.066 & 200 & - \\
\hline $\mathrm{Mg}^{2+}(\mathrm{mg} / \mathrm{l})$ & 3 & 0.05 & 30 & 30 \\
\hline $\mathrm{K}^{+}(\mathrm{mg} / \mathrm{l})$ & 2 & 0.033 & - & 10 \\
\hline $\mathrm{Ca}^{2+}(\mathrm{mg} / \mathrm{l})$ & 3 & 0.05 & 75 & 75 \\
\hline $\mathrm{F}^{-}(\mathrm{mg} / \mathrm{l})$ & 5 & 0.083 & 1 & 1 \\
\hline $\mathrm{Cl}^{-}(\mathrm{mg} / \mathrm{l})$ & 5 & 0.083 & 250 & 250 \\
\hline $\mathrm{So}_{4}{ }^{-}(\mathrm{mg} / \mathrm{l})$ & 4 & 0.066 & 250 & 200 \\
\hline $\mathrm{No}_{3}{ }^{-}(\mathrm{mg} / \mathrm{l})$ & 5 & 0.083 & 45 & 45 \\
\hline $\begin{array}{l}\mathrm{Hco}_{3}^{-} \\
(\mathrm{mg} / \mathrm{l})\end{array}$ & 1 & 0.016 & 200 & - \\
\hline $\mathrm{Fe}(\mu \mathrm{g} / \mathrm{l})$ & 4 & 0.066 & - & 300 \\
\hline $\operatorname{Mn}(\mu \mathrm{g} / \mathrm{l})$ & 4 & 0.066 & 100 & 100 \\
\hline $\mathrm{Pb}(\mu \mathrm{g} / \mathrm{l})$ & 4 & 0.066 & 10 & 10 \\
\hline $\mathrm{Zn}(\mu \mathrm{g} / \mathrm{l})$ & $\begin{array}{l}3 \\
\Sigma 60\end{array}$ & 0.05 & - & 5000 \\
\hline
\end{tabular}
et al. 2021a, b, c)

\section{Heavy metal pollution index (HPI)}

HPI has been used to evaluate water quality and its suitability for drinking (Rezaei et al. 2017). HPI has been calculated applying the formula.

$W_{i}=\frac{K}{M A C}$

$Q_{i}=\sum_{i=1}^{n} \frac{\left\{\left(M_{i}-I_{i}\right)\right\}}{\left(S_{i}-I_{i}\right)} \times 100$

$\mathrm{HPI}=\frac{\sum_{i=1}^{n} W_{i} \times Q}{\sum_{i=1}^{n} W_{i}}$

where Wi indicates weightage of each metal, MAC indicates Maximum Allowable Concen tration of each metal as suggested by Bureau of Indian Standard (BIS 2012). ' $\mathrm{K}$ ' is constant value, Qi shows quality rating of each metal, Mi denotes measured concentration of respective heavy metal, Ii is ideal value and $\mathrm{Si}$ is standard value of each metal as prescribed by BIS 2012. The critical value of heavy metal pollution index is 100. HPI $>1$ indicates unsuitable for drinking purpose.

\section{Irrigation water quality}

Irrigation water quality of Santuri block was determined by various indices using certain chemical parameters which are as follows: (Richards 1954), (Todd 1980), (Doneen 1964), (Raghunath 1987), (Kelly 1976)

Sodium adsorption ration $(\mathrm{SAR})=\frac{\mathrm{Na}^{2+}}{\sqrt{\frac{\mathrm{Ca}^{2+}+M g^{2+}}{2}}}$

Soluble sodium percentage (SSP) $=\frac{\left(N a^{2+} K^{+}\right) \times 100}{\left(C a^{2+}+M g^{2+}+N a^{2+}+K^{+}\right)}$

Permeability Index $(\mathrm{PI})=\frac{\left(\mathrm{Na}^{2+}+\sqrt{\mathrm{HCO}_{3}^{-}}\right) \times 100}{\left(\mathrm{Ca}^{2+}+\mathrm{Mg}^{2+}+\mathrm{Na}^{2+}\right)}$

Magnesium adsorption ratio $(\mathrm{MAR})=\frac{M g^{2+} \times 100}{C a^{2+}+M g^{2+}}$

Kelly's ratio $(K R)=\frac{N a^{2+}}{\left(C a^{2+}+M g^{2+}\right)}$ 
All ionic concentrations were calculated by meq/l.

\section{Human health risk (HHR)}

Human non-carcinogenic health risks (via oral consumption) of heavy metals in drinking water were evaluated for children and adult residents of Santuri block. Traditional USEPA (2011) method was applied using the following formulas.

$\mathrm{CDI}_{\text {Oral }}=\frac{C_{W} \times I_{R} \times E F \times E D}{B W \times A T}$

$\mathrm{HQ}_{\text {Oral }}=\frac{C D I}{R f D}$

$\mathrm{HI}_{\text {Oral }}=\sum_{i=1}^{n} H Q$

where $\mathrm{CDI}_{\text {oral }}$ is chronic daily dose intake via oral pathway and expressed in $\mu \mathrm{g} / \mathrm{kg} /$ day. $\mathrm{C}_{\mathrm{w}}$ is respective concentration in sample water $(\mu \mathrm{g} / \mathrm{l})$. IR is ingestion rate of water $(0.70 \mathrm{lit}$ for children and 2 lit for adult), EF is exposure frequency (365 days) for children and adult, respectively). BW denotes body weight of children (15 kg) and adult (70 kg), AT is average time (2190 days for children and 10,950 days for adult), and $\mathrm{RfD}(\mu \mathrm{g} / \mathrm{kg} /$ day) represents reference dose of heavy metals in drinking water suggested by USEPA (2011).
HQ indicates Hazard Quotient (unitless) and HI signifies Hazard Index (unitless). HI value $<1$ suggests no immediate health hazard, and $\mathrm{HI}>1$ shows possibilities of health hazard in the assessed area (Yang et al. 2012).

\section{Statistical and spatial techniques}

Descriptive statistics and index analysis were applied applying SPSS 16 software. Spatial mapping of water quality in pre- and post-monsoon season was performed using inverse distance weighted (IDW) method in ArcGIS 10.4 software. IDW is such useful technique which is used to interpolate of cell values by linear weighted combination of a sample point (Adhikary et al. 2011; Bhunia et al. 2018). In this method, best prediction of neighboring samples value was obtained from observed data and estimated data (Yao et al. 2013).

\section{Results and discussion}

\section{General hydrochemistry of the groundwater}

The statistical summary of groundwater samples in premonsoon season (Table 2) showed that the mean concentration of $\mathrm{pH}$ (7.66), EC (1100.00), TDS (704) stands acceptable limit according to WHO (2011) guidelines and indicated weak alkaline-type water. Total hardness (TH) exceeded its permissible limit in this season. During post-monsoon season, mean value of $\mathrm{pH}$ (7.46), EC

Table 2 Statistical summary of physiochemical and heavy metal parameters in groundwater of pre and post monsoon season

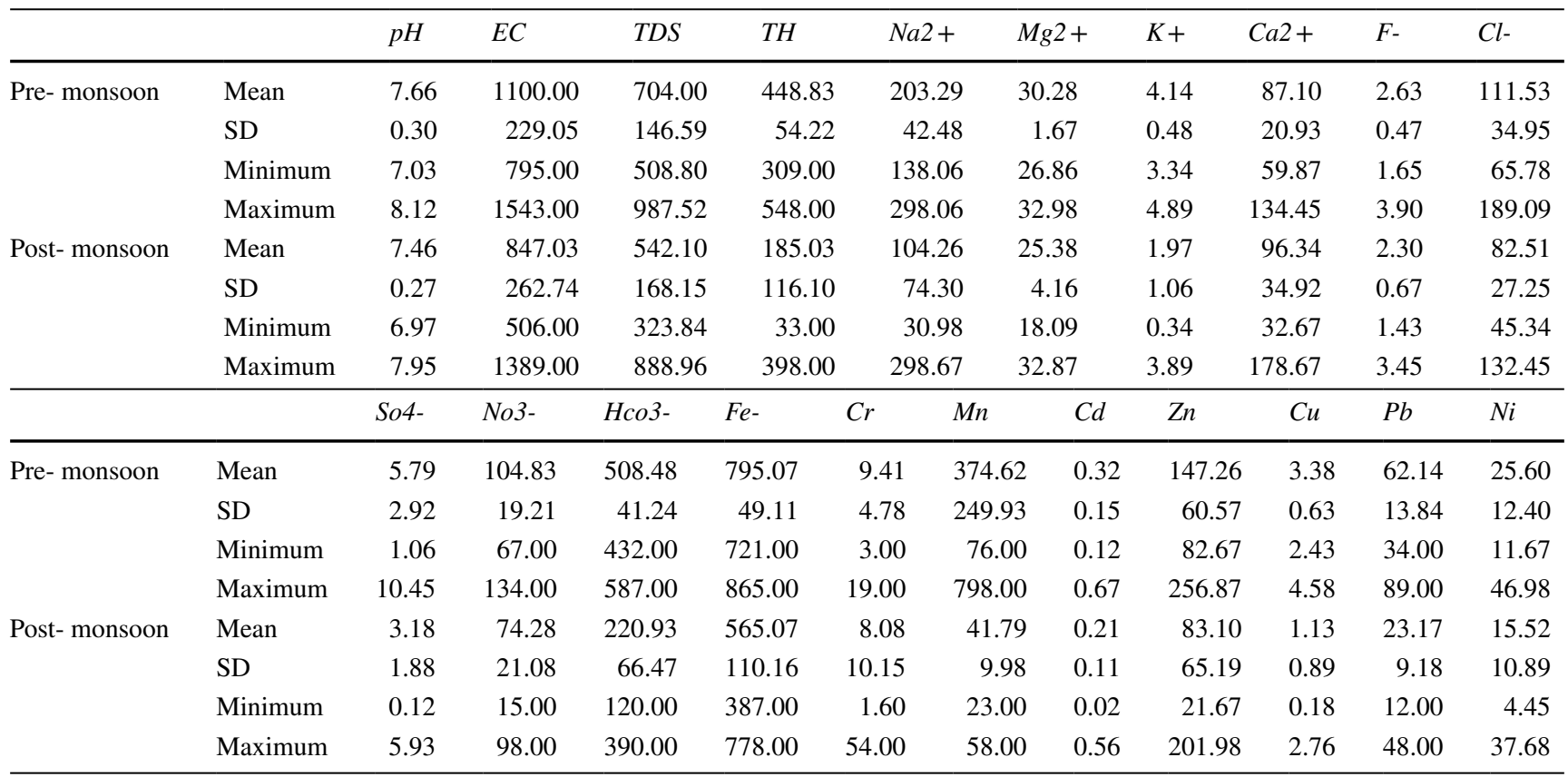

SD Standard deviation 
(847.03) and TDS (542.10) also showed the permissible limit. In this period, TH was below permissible limit due to high availability of water supply in subsurface area. In both pre- and post-monsoon seasons, cation concentration of GW was in an order of $\mathrm{Na}^{2+}>\mathrm{Ca}^{2+}>\mathrm{Mg}^{2+}>\mathrm{K}^{+}$ by their mean values. Anion was in their descending order of $\mathrm{Hco}_{3}{ }^{-}>\mathrm{No}_{3}{ }^{-}>\mathrm{Cl}^{-}>\mathrm{So}_{4}{ }^{-}>\mathrm{F}^{-} . \mathrm{Na}^{2+}$ and $\mathrm{Ca}^{2+}$ exceeded their permissible limit in groundwater. It can be due to higher ionic modification between these two cations and weathering of silicate minerals (Islam et al. 2017a). On the other hand, $\mathrm{Hco}_{3}{ }^{-}$(508.48), $\mathrm{No}_{3}{ }^{-}$(104.83) and $\mathrm{F}^{-}$(2.63) crossed their upper permissible limit because of agricultural fertilizer and pesticides contamination in groundwater. Geologically, the region is composed by fluoride-bearing host rocks and minerals. Therefore, natural concentration and contamination of $\mathrm{F}^{-}$has been increased in GW. The presence of $\mathrm{Cl}^{-}$and $\mathrm{SO}_{4}{ }^{-}$in the aquifer system was due to weathering of silicate minerals and gypsum (Fisher and Mullican Iii 1997). Mean concentration of heavy metals in groundwater of pre- and post-monsoon season showed their descending order of accumulation as
$\mathrm{Fe}>\mathrm{Mn}>\mathrm{Zn}>\mathrm{Pb}>\mathrm{Ni}>\mathrm{Cr}>\mathrm{Cu}>\mathrm{Cd}$. Natural weathering of iron-rich minerals and mixing of agricultural, industrial effluents with subsurface water are the main causes of higher availability of heavy metals in this area. In both the seasons, all heavy metals exceeded their acceptable limit according to BIS (2012).

Ionic balance of 29 sample water in pre-monsoon showed that no sample was fresh type (value between $-10 \%$ and $+10 \%)$ in this season. In post-monsoon season, $31.03 \%$ sample indicated fresh or good type water with low TDS value by their ionic concentration (Table 3 ).

\section{Groundwater quality index}

Groundwater quality of Santuri block showed the range from 132.19 to 210.63 with 171.22 mean value. In this season, $76.66 \%$ water samples were 'poor' quality and $23.33 \%$ were 'very poor' quality of groundwater (Table 3). On the other hand, GWQI of post-monsoon season showed the ranges from 79.92 to 123.28 with 96.49 mean value. $66.66 \%$ groundwater samples appeared as 'good' quality
Table 3 Sample-wise classification of different water quality indices for drinking and irrigation purpose

\begin{tabular}{|c|c|c|c|c|}
\hline Indices & Range & Category & $\begin{array}{l}\% \text { of samples (pre- } \\
\text { monsoon) }\end{array}$ & $\begin{array}{l}\% \text { of samples } \\
\text { (post-mon- } \\
\text { soon) }\end{array}$ \\
\hline \multirow[t]{5}{*}{ GWQI } & $<50$ & Excellent & 0 & 0 \\
\hline & $50-100$ & Good & 0 & 66.66 \\
\hline & $101-200$ & Poor & 76.66 & 33.33 \\
\hline & $201-300$ & Very poor & 23.33 & 0 \\
\hline & $>300$ & Unsuitable for drinking & 0 & 0 \\
\hline \multirow[t]{3}{*}{ HPI } & $<100$ & No pollution & 6.89 & 93.10 \\
\hline & $100-150$ & Medium pollution & 55.17 & 6.89 \\
\hline & $>150$ & High pollution & 37.93 & 0 \\
\hline \multirow[t]{4}{*}{ SAR } & $0-18$ & Excellent & 93.10 & 93.10 \\
\hline & $10-18$ & Good & 6.89 & 6.89 \\
\hline & $18-26$ & Permissible & 0 & 0 \\
\hline & $>26$ & Doubtful & 0 & 0 \\
\hline \multirow[t]{5}{*}{ SSP } & $<20$ & Excellent & 0 & 10.34 \\
\hline & $20-40$ & Good & 0 & 48.27 \\
\hline & $40-60$ & Permissible & 20.68 & 41.37 \\
\hline & $60-80$ & Doubtful & 79.31 & 0 \\
\hline & $>80$ & Unsuitable & 0 & 0 \\
\hline \multirow[t]{3}{*}{ PI } & $<80$ & Good & 3.44 & 31.03 \\
\hline & $80-100$ & Moderate & 72.41 & 31.03 \\
\hline & $100-120$ & Poor & 24.13 & 37.93 \\
\hline \multirow[t]{2}{*}{ MAR } & $<50$ & Suitable & 100 & 100 \\
\hline & $>50$ & Unsuitable & 0 & 0 \\
\hline \multirow[t]{2}{*}{ KR } & $<1$ & Suitable & 0 & 68.96 \\
\hline & $>1$ & Unsuitable & 100 & 31.03 \\
\hline \multirow[t]{2}{*}{ Ionic balance } & $-10 \%-+10 \%$ & Fresh water & 0 & 31.03 \\
\hline & $>+10 \%$ & Polluted water & 100 & 68.97 \\
\hline
\end{tabular}


Fig. 2 Spatial distribution of groundwater quality (GWQ) and Heavy metal Pollution Index (HPI)
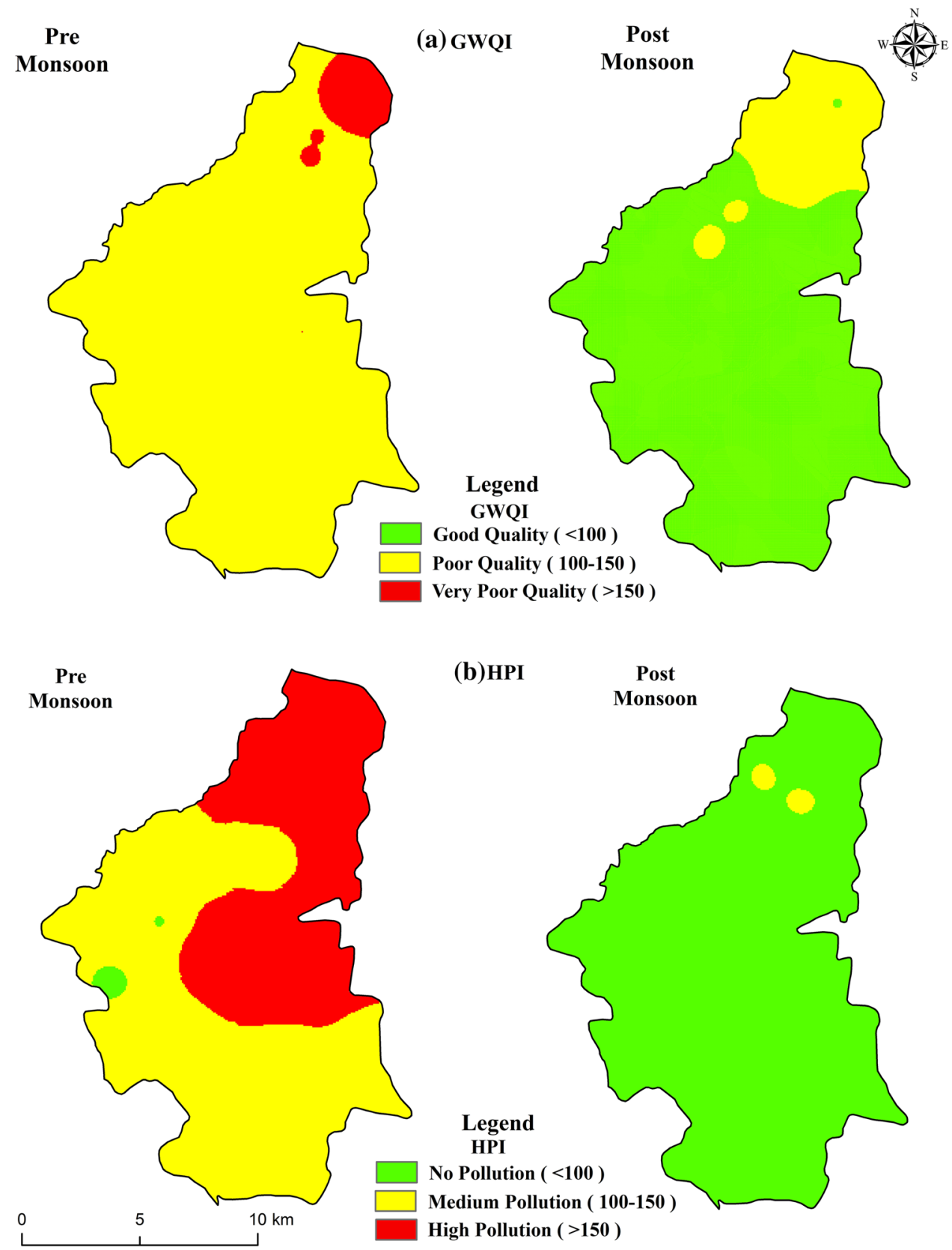

and $33.33 \%$ water samples appeared as 'poor' quality for drinking purpose in post-monsoon. In pre-monsoon, lowering down of groundwater quality is mainly due to increase in ionic exchange activities in aquifer zone. But in post-monsoon season, higher availability of water recharge helped to ameliorate water quality for drinking purpose. Similar results have been found in previous researches on groundwater quality of Purulia district (Kundu and Nag 2018; Chakraborty et al. 2021a, b, c). Spatial pattern of GWQI showed (Fig. 2) deterioration of water quality in industrial belt of northern part of Santuri block.

\section{Heavy metal pollution index (HPI)}

Drinking water suitability on the basis of heavy metal contamination of Santuri block by HPI method showed the ranges from 82.56 to 197.11 with 142.28 mean value in pre-monsoon season. Around $93.34 \%$ and $6.66 \%$ sample water was observed as highly and no pollution particularly in monsoon season (Table 3). In post-monsoon season, HPI was ranging from 32.31 to 113.80 with 58.43 mean value. In this season, $6.66 \%$ water sample indicated 'high pollution' and $93.34 \%$ samples indicated 'no pollution' $(\mathrm{HPI}<100)$ for drinking purpose. In pre-monsoon season, higher leaching of heavy metals by irrigated water increased metal 
contamination than post-monsoon season. Spatial distribution of HPI was classified into three categories as no pollution (HPI < 100), medium pollution (HPI $=100-150)$ and high pollution (HPI $>150)$ and it showed that the northern and eastern part of this block was highly polluted by heavy metal contamination in pre-monsoon season (Fig. 2).

\section{Assessment of irrigation water quality}

Irrigation water is mixed with excess chemical components originated by either geogenic or anthropogenic factors which can negatively affect to the soil fertility, water permeability and crop production efficiency (Jalali 2009). Excess supply of irrigation water in agricultural field is generally responsible for existence of alkalis and salt on the top layer of soil and it provides salt to the crop roots (Jalali 2011). In this context, irrigation water quality of Santuri block has been assessed through SAR, SSP, PI, MAR, KR to determine chemical effects on crop production in this block (Liu et al. 2021).

\section{Sodium adsorption ratio (SAR)}

Excess concentration of sodium in GW produces alkalinetype soil. It increases soil compactness and lowered down percolation capacity of rain water into soil. Alkaline soil is considered as poor quality for agricultural production without irrigation. Cultivation is difficult in this type of soil particularly in dry period. In Santuri block, irrigation water quality by SAR showed the range from 4.53 to 13.04 with 7.12 mean value in pre-monsoon season. In post-monsoon season, SAR ranged from 0.87 to 11.77 with 3.83 mean value. In both the seasons, $93.10 \%$ samples were under 'excellent' quality and $6.89 \%$ 'good' quality samples were observed (Table 3). The increase in ionic interactions, climatic influence, leaching of fertilizer, pesticides from topsoil by irrigated water promotes SAR in groundwater in pre-monsoon season. Overall groundwater of Santuri block suggested water suitability for crop production (by SAR method). Spatial pattern of SAR in pre- and post-monsoon season is presented in Fig. 3.

\section{Soluble sodium percentage (SSP)}

Irrigation water is mixed with high sodium content which can be absorbed by clay minerals as a dispersing for calcium and magnesium ions. It makes soil harder, reduces the water infiltration rate and leads to low crop production capacity of soil (Singh et al. 2008). SSP analyzed the GW of premonsoon season that is ranged from 53.77 to 76.80 with 63.70 mean value. In this period, $20.68 \%$ samples showed 'permissible' water and $79.31 \%$ sample showed 'doubtful' for irrigation purpose (Table 3). In post-monsoon season, SSP is ranged from 19.02 to 74.58 with 42.82 mean value. In this period, $48.27 \%$ samples indicated 'good' for irrigation. $10.34 \%$ samples showed excellent for crop production
Fig. 3 Spatial distribution of irrigation water quality

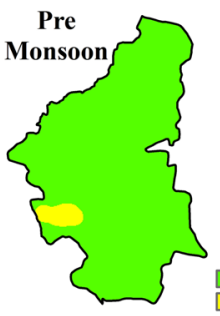

(a) SAR
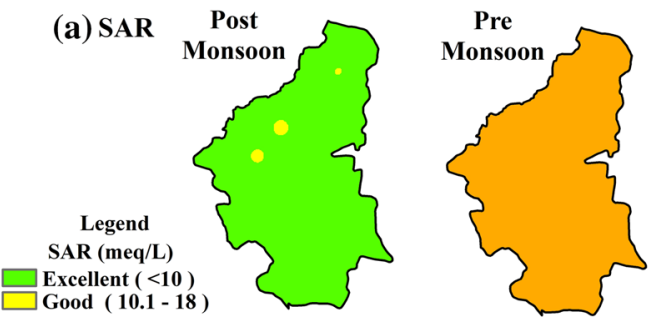

(b) SSP

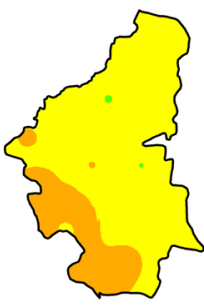

(c) PI
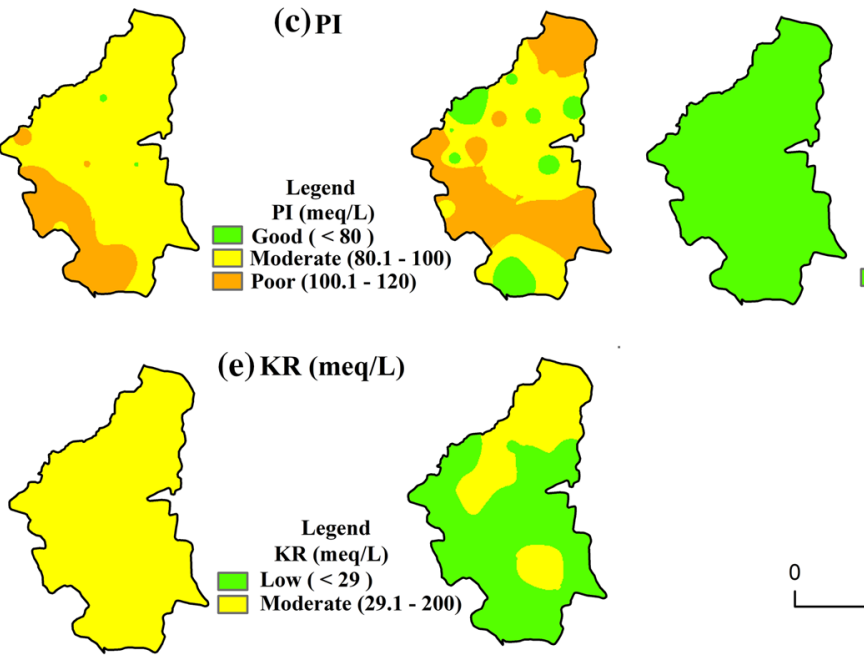

(e) KR (meq/L)

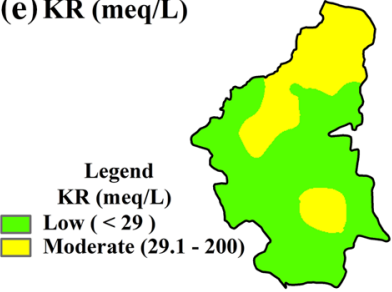

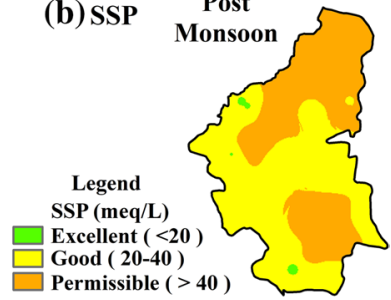

(d) MAR
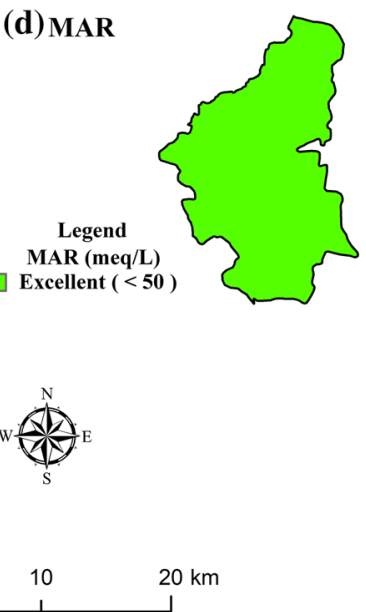
while $41.37 \%$ samples presented 'permissible' for agricultural usages. Mean SSP of pre-monsoon was higher than post-monsoon season and it indicated lower suitability of groundwater for irrigation in pre-monsoon. Spatial distribution of SSP in pre- and post-monsoon season of Santuri block is presented in Fig. 3.

\section{Permeability index (PI)}

Sodium, calcium, bicarbonate and magnesium ions are the main controlling factors of permeability of soil. Permeability Index showed the quality of GW to soil permeability in any region. PI of pre-monsoon season showed the range from 79.66 to 114.80 with 94.59 mean value. $3.44 \%$ sample water showed 'good' for soil permeability. $72.41 \%$ sample showed 'moderate' for soil permeability and $24.13 \%$ sample indicated 'poor' for soil permeability (Table 3 ). In postmonsoon season, PI ranged from 49.06 to 152.25 with 95.94 mean value. $31.03 \%$ samples indicated 'good' quality while $31.03 \%$ samples showed 'moderate' quality and $37.93 \%$ sample indicated 'poor' quality for permeability. Spatial distribution of PI in the study area is presented in Fig. 3.

\section{Magnesium adsorption ratio (MAR)}

Suitable quantity of magnesium ion is very helpful for plant growth. But high availability of $\mathrm{Mg}^{2+}$ affects the plant health and reduces soil infiltration rate. High level of magnesium can decrease the presence of $\mathrm{K}^{+}$in soil. Therefore, MAR is suggested for groundwater irrigation (Kacmaz and Nakoman 2009) in the study area. MAR of pre-monsoon is ranged from 17.39 to 37.43 with 26.92 mean value. In post-monsoon, MAR is ranged from 10.45 to 46.10 with 22.99 mean value. In both seasons, $100 \%$ sample water indicated suitability of GW in respect of magnesium content for irrigation purpose (Table 3). Spatial zonation of MAR in Santuri block is presented in Fig. 3.

\section{Kelley's ratio (KR)}

Kelley's ratio is based on sodium availability of groundwater for irrigation. Sodium mainly is originated from natural weathering of feldspar minerals. KR $>1$ suggests higher sodium content and unsuitability for irrigation. In pre-monsoon season, KR is ranged from 1.13 to 3.26 with 1.78 mean value. $100 \%$ sample of this season indicated $K R>1$, hence unsuitability for irrigation (Table 3). In post-monsoon season, $\mathrm{KR}$ is ranged from 0.21 to 2.92 with 0.95 mean value. $68.96 \%$ water samples showed KR $>1$, i.e., 'suitable' and $31.03 \%$ sample showed $\mathrm{KR}<1$, i.e., 'unsuitable' for agricultural purpose. Spatial pattern of KR is presented in Fig. 4.

\section{Assessment of human health risk (HHR)}

Toxicity of groundwater on the basis of heavy metal consumption via oral ingestion of drinking water can give significant impact on human health (Rasool et al. 2017; Ahmed et al. 2019). Long-term ingestion of heavy metals can cause chronic non-carcinogenic or carcinogenic-type diseases (Islam et al. 2019). In the Santuri block, susceptibility of non-carcinogenic health risk by ingestion of groundwater was evaluated for both children and adult population. Heavy metal such as $\mathrm{Fe}, \mathrm{Cr}, \mathrm{Cd}, \mathrm{Zn}, \mathrm{Mn}, \mathrm{Cu}$ and $\mathrm{Pb}$ were considered for health risk assessment. The total HI (Hazard Index) value of children in pre-monsoon and post-monsoon was ranged from 0.68 to 1.49 with 1.14 mean value and 0.28 to 1.21 with 0.50 mean value, respectively. Mean value of $\mathrm{HI}$ (children) of pre-monsoon was higher $(\mathrm{HI}>1)$ than post-monsoon $(\mathrm{HI}<1)$ which indicated more potentiality to health hazard during pre-monsoon season. In pre-monsoon, $27.58 \%$ samples indicated $\mathrm{HI}<1$ and suggested no immediate health risk in this region. $72.40 \%$ water sample showed $\mathrm{HI}>1$ and indicated health hazard of children during this period (Table 4). HI values of post-monsoon season indicated that $100 \%$ samples were safe for drinking and no possibilities of health risk of children in this season.

During pre-monsoon, HI values of adults ranged from 0.43 to 0.94 with 0.71 mean value. In post-monsoon, HI of adults ranged from 0.17 to 0.74 with 0.31 mean value. $100 \%$ samples of both seasons indicated safe for oral consume $(\mathrm{HI}<1)$ for adult population. Children were found more susceptible to health hazard than adult in this block as indicated by their average values. This is because of children have lower body weight and low metabolism power than adults. Similar results have been found in previous studies also (Kabir et al. 2020; Ojekunle et al. 2016; Tiwari et al. 2015; Sharma et al. 2019; Chakraborty et al. 2021a, b, c). Spatial interpolation mapping showed that high health risk was found in industrially developed northern part of Santuri block (Fig. 4).

\section{Remedial techniques}

Safe and healthy groundwater is always desirable for people of green globe. It ensures human health and hygiene and also protects the environment. Good quality of groundwater helps to promote crop growth and it maintains soil quality. Therefore, appropriate monitoring and innovative measurement techniques are effective weapon for sustainable natural resource management. There are mainly two types of remediation techniques in this field, i.e., in situ and ex situ. In situ process is involved for groundwater treatment by different thermal, biological or chemical techniques within the aquifer. Ex situ process involves the water treatment by 
Fig. 4 Spatial distribution of susceptible to human health risks
Pre

Monsoon

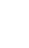

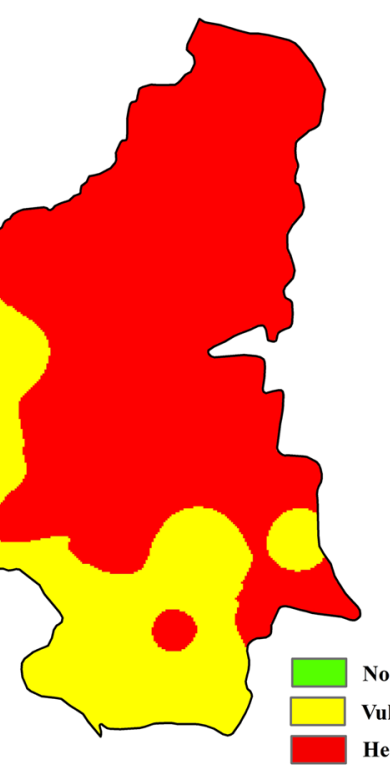

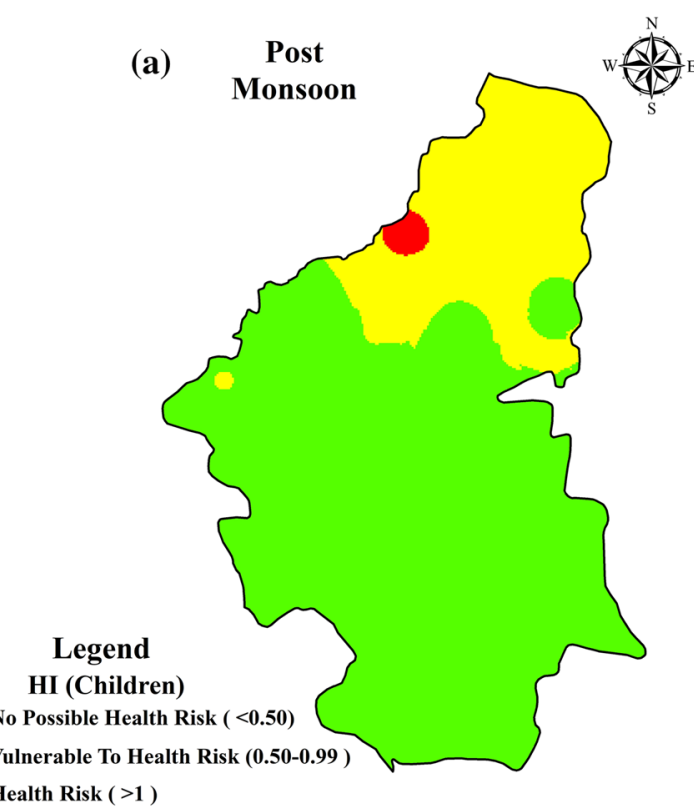

(a)
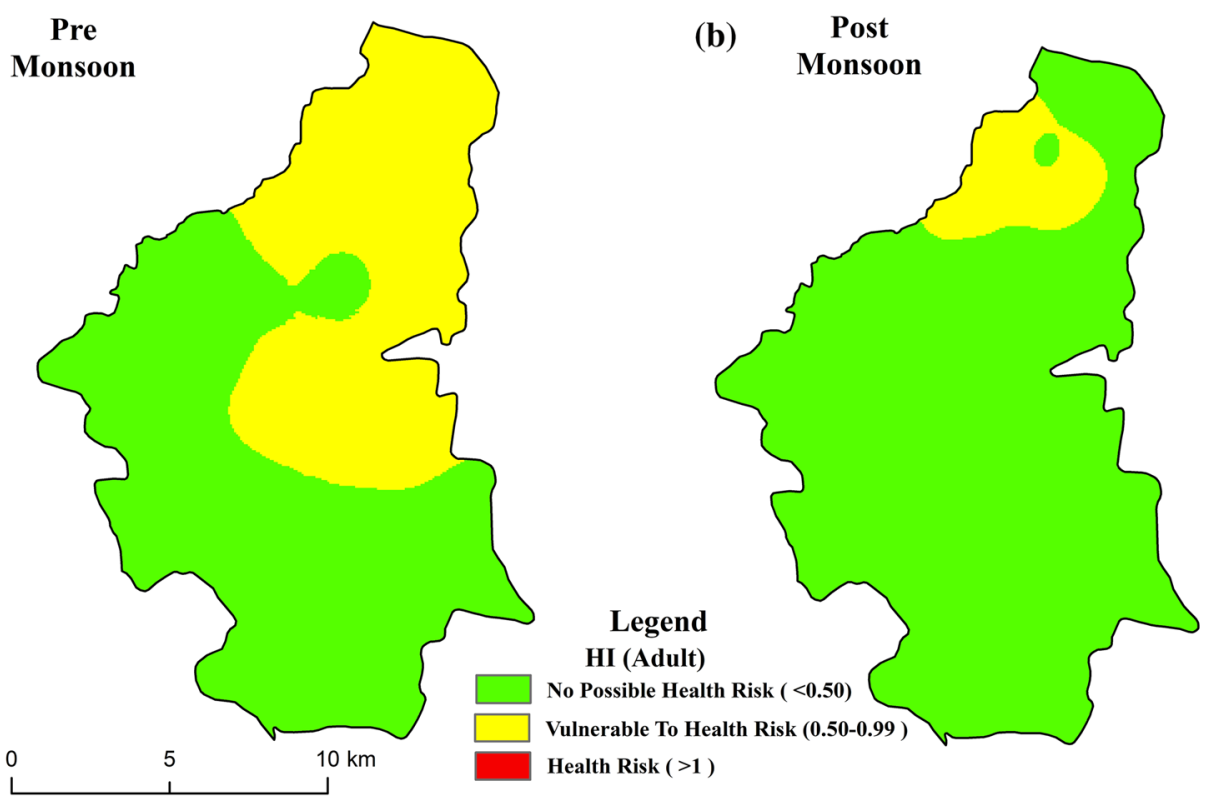

Table 4 Sample under noncarcinogenic human health risk in pre- and post-monsoon season

\begin{tabular}{|c|c|c|c|c|c|c|}
\hline \multirow[t]{2}{*}{$\begin{array}{l}\text { Hazard Index } \\
\text { (HI) }\end{array}$} & \multirow[t]{2}{*}{ Range } & \multirow[t]{2}{*}{ Category } & \multicolumn{2}{|c|}{$\begin{array}{l}\% \text { of sample under pre- } \\
\text { monsoon }\end{array}$} & \multicolumn{2}{|c|}{$\begin{array}{l}\% \text { of samples under } \\
\text { post-monsoon }\end{array}$} \\
\hline & & & Children & Adult & Children & Adult \\
\hline & $<1$ & No immediate health risk & 27.58 & 100 & 100 & 100 \\
\hline & $>1$ & Possibilities of health risk & 72.40 & 0 & 0 & 0 \\
\hline
\end{tabular}

extracting contaminated groundwater from aquifer. Generally, two methods are highly expensive. Therefore, some cost-effective and efficient remediation will be more helpful for common people and government of developing countries.

\section{Conclusion}

The present study on groundwater quality of Santuri block of Purulia district has been analyzed for suitability of drinking, irrigation and human health $\mathrm{s}$ in different seasons. The 
analytical result of groundwater hydrochemistry showed that the GW is mainly low alkaline type with acceptable concentration of EC and TDS in both seasons. High concentration of $\mathrm{Na} 2+, \mathrm{Ca} 2+$ in groundwater was due to weathering of silicate minerals. Agricultural activities lead to an increase in the level of Hco3-, No3- and F- in groundwater. Heavy metals like iron and manganese are found higher amount than their standard limit because of weathering of parent rocks in this region. Various ions are released from the weathered hillocks and these are being mixed in the soil and water. Drinking water suitability by GWQI and HPI showed the significant deterioration of water quality in pre-monsoon in comparison with post-monsoon. Irrigation water quality (by SAR, SSP, PI, MAR, KI) gives overall suitability of GW for agricultural practices. However, groundwater of pre-monsoon has low suitability than post-monsoon due to amplification of ionic activities in summer season. Human health risk of non-carcinogenic diseases suggested that children were more vulnerable than adult in this block and obvious health risk was found for children ( $\mathrm{HI}>1$ ) particularly in pre-monsoon season. This applied research will assist to policy makers and government will take necessary steps for the improvement of public health applying emergency mitigation measures. There is a huge scope for scholars and researchers to find out a new innovative ideas and models considering the natural hydrogeomorphic diversity and modern societal integrity.

Acknowledgements The authors show their kind acknowledgment to the Department of Geography and Microbiology, Raja N. L. Khan Women's College (Autonomous), Department of Geology \& Geophysics, Indian Institute of Technology (IIT), Kharagpur, West Bengal, India, for their laboratory facilities and kind encouragement.

Author contributions P.K.Shit conceptualized and planned the study and reviewed and edited the manuscript. B. Chakraborty conducted the survey and water sampling, analyzed the data and interpreted the results. S.Roy conducted the survey, water sampling, prepared the maps. S. Bhattacharjee reviewed and edited the manuscript. P.P.Adhikary reviewed and edited the manuscript. B. Bera supervised the study and reviewed and edited the manuscript. D. Sengupta supervised the overall research, interpreted the results. All authors have read and approved the final manuscript.

Funding This research was supported by the Department of Geography, Raja N. L. Khan Women's College (Autonomous), affiliated to Vidyasagar University, Midnapore, West Bengal, India. The author (P. K. Shit) grateful acknowledges West Bengal DSTBT for financial support through R\&D Research Project Memo no. 104(Sanc.)/ST/P/S\&T/ 10G-5/2018).

Data availability The datasets used and analyzed during the current study are available from the corresponding author on reasonable request.

\section{Declarations}

Conflict of interest The authors declare that they have no competing interests.
Open Access This article is licensed under a Creative Commons Attribution 4.0 International License, which permits use, sharing, adaptation, distribution and reproduction in any medium or format, as long as you give appropriate credit to the original author(s) and the source, provide a link to the Creative Commons licence, and indicate if changes were made. The images or other third party material in this article are included in the article's Creative Commons licence, unless indicated otherwise in a credit line to the material. If material is not included in the article's Creative Commons licence and your intended use is not permitted by statutory regulation or exceeds the permitted use, you will need to obtain permission directly from the copyright holder. To view a copy of this licence, visit http://creativecommons.org/licenses/by/4.0/.

\section{References}

Acheampong SY, Hess JW (1998) Hydrogeologic and hydrochemical framework of the shallow groundwater system in the Southern voltaian sedimentary basin. Ghana J Hydrogeol 6(4):527-537

Adhikary PP, Biswas H (2011) Geospatial assessment of groundwater quality in Datia district of Bundelkhand. Indian J Soil Conserv 39(2):108-116

Adimalla N, Qian H (2019) Groundwater quality evaluation using water quality index(WQI)for drinking purposes and human health risk (HHR) assessment in an agricultural region of Nanganur, south India. Ecotoxicol Environ Saf 176:153-161. https://doi.org/10. 1016/j.ecoenv.2019.03.066

Adimalla N, Wu J (2018) Groundwater quality and associated health risks in a semi-arid region of south India: implication to sustainable groundwater management. Hum Ecol Risk Assess: An Int J. https://doi.org/10.1080/10807039.2018.1546550

Ahmed N, Bodrud-DozaM, IslamARMT, Hossain S, MoniruzzamanM, Dev N, Bhuiyan MAQ (2019) Appraising spatial variations of As

Ahmed S, Kayes I, Shahriar SA, Kabir M, Salam MA, Mukul S (2020) Soil salinity and nutrients pattern along a distance gradient in coastal region. Global J Environ Sci Manage 6:59-72

Ahmed F, Fakhruddin ANM, Fardous Z, Chowdhury MAZ, Kabir MM (2021) Accumulation and translocation of chromium (Cr) and lead $(\mathrm{Pb})$ in chilli plants (Capsicum annuum L.) grown on artificially contaminated soil. Nat Environ Pollut Technol 20:63-70

Al-Futaisi A, Rajmohan N, Al-Touqi S (2007) Groundwater quality monitoring in and around Barka dumping site, Sultanate of OmanIn: Proceedings of second IASTED WRM conference

Al-Sudani HIZ (2003) Hydrogeological System of Debagah Basin InNorth of Iraq, Ph.D. Thesis , University of Baghdad, Collegeof Science. $153 \mathrm{p}$

Al-Sudani HIZ (2019) A review on groundwater pollution. Int J Recent Eng Sci (IJRES) 6(5):2349-7157

Amirabdollahian M, Datta B (2013) Identification of contaminant source characteristics and monitoring network design in groundwateraquifers: an overview. J Environ Prot 4:26-41

Ashraf M, Afzal M, Ahmad R, Ali S (2011) Growth and yield components of wheat genotypes as influenced by potassium and farm yard manure on a saline sodic soil. Soil Environ 30:115-121

Ashwani KT, Abhay KS (2014) Hydrochemical investigation and groundwater quality assessment of Pratapgarh District, Uttar Pradesh. J Geol Soc India 83:329-343

Bhuiyan MAH, Bodrud-Doza M, Islam ARMT, Rakib MA, Rahman MS, Ramanathan AL (2016) Assessment of groundwater qualityof Lakshimpur district of Bangladesh using water quality indices, geostatistical methods, and multivariate analysis. Environ Earth Sci 75:1020. https://doi.org/10.1007/s12665-016-5823-y 
Bhunia GS, Keshavarzi A, Shit PK, El-Sayed Oman E, Bagherzadeh A (2018) Evaluation of groundwaterquality and its suitability for drinkingand irrigation using GIS and geostatistics techniques in semiarid region of Neyshabur. Iran Appl Water Sci. https://doi. org/10.1007/s13201-018-0795-6

BIS (Bureau of Indian Standards) (2012) Indian Standard, Drinking Water-Specification, Second Revision, IS 10500: ICS 13.060.20

Carpenter SR, Caraco NF, Crrell DL, Howarth RW, Sharpley AN, Smith VH (1998) Non point of surface waters with phosphorous and nitrogen. Ecol Appl 8(3):559-568

Central Water Commission (CWC) (2006) Water and related statistics. Central Water Commission, Ministry of Water Resources, Government of India, New Delhi

Chakraborty B, Roy S, Bera A, Adhikary PP, Bera B, Sengupta D, Bhunia GS, Shit PK (2020) Cleaning the river Damodar (India): impact of COVID-19 lockdown on water quality and future rejuvenation strategies. Environ Dev Sustain. https://doi.org/10.1007/ s10668-020-01152-8

Chakraborty B, Bera B, Roy S, Adhikary S, Shit PK (2021) Assessment of non-carcinogenic health risk of heavy metal pollution: evidence from coal mining region of eastern India. Environ Sci Pollut Res. https://doi.org/10.1007/s11356-021-14012-3

Chakraborty B, Roy S, Bera A, Adhikary PP, Bera B, Sengupta D, Bhunia GS, Shit PK (2021) Eco-restoration of river water quality during COVID-19 lockdown in the industrial belt of eastern India. Environ Sci Pollution Res. https://doi.org/10.1007/ s11356-021-12461-4

Chakraborty B, Roy S, Bhunia GS, Sengupta D, Shit PK (2021c) Groundwater quality through multi- criteria -based GIS analysis: village level assessment. Groundw Soc. https://doi.org/10.1007/ 978-3-030-64136-8_6

Chandrasekar N, Selvakumar S, Srinivas Y, Jhon Wilson JS, Simon Peter T, Magesh NS (2014) Hydrochemical assessment of groundwater quality along the coastal aquifers of southern Tamilnadu, India. Environ Earth Sci 71:4739-4750

Doneen LD (1964) Water quality for agriculture. University of California, Davis, Department of Irrigation

Edet AE, Offiong OE (2002) Evaluation ofwater quality pollution indices for heavy metal contamination monitoring: a study case fromAkpabuyo-Odukpani area lower cross river Basin (southeastern Nigeria). Geo J 5:295-304

Fisher RS, Mullican Iii WF (1997) Hydrochemical evolution of sodiumsulfate and sodium-chloride groundwater beneath the northern Chihuahuan Desert, Trans-Pecos, Texas, USA. Hydrogeol J $5: 4-16$

Foster S, Chilton J, Moench M, Cardy F, Schiffer M (2000) Groundwater in rural development, World Bank technical paper, 463

Gautam SK, Maharana C, Sharma D, Singh AK, Tripathi JK, SinghSK, (2015) Evaluation of groundwater quality in the chotanagpurplateau region of the Subarnarekha river basin, Jharkhand State, India. Sustain Water Qual Ecol 6:57-74

Hasan MK, Shahriar A, Jim KU (2019) Water pollution in Bangladeshand its impact on public health. Heliyon 5:e02145. https://doi. org/10.1016/j.heliyon.2019.e02145

Hem jd (1991) Study and interpretation of the chemical characterististics of natural water. Scientific publishers: jodhpur. India ; 2254

Huh Y, Tsoi M, Zaitiser A, Edward JN (1998) The fluvial geochemistry of the river of Eastern Siberia. I. Tributaries of Lena River draining the sedimentation platform of the Siberia Craton. Geochim Cosmochim Acta 62:1657-1676

Islam ARMT, Ahmed N, Bodrud-Doza M, Chu R (2017a) Characterizing groundwater quality ranks for drinking purposes in Sylhet district, Bangladesh, using entropy method, spatial autocorrelation index, and geostatistics. Environ Sci Pollut Res 24(34):2635026374. https://doi.org/10.1007/s11356-017-0254-1
Islam ARMT, Shen S, Bodrud-Doza M et al (2017b) Assessment of trace elements of groundwater and their spatial distribution in Rangpur district. Bangladesh. Arab J Geosci 10(4):95. https://doi. org/10.1007/s12517-017-2886-3

Islam ARMT, Bodrud-doza M, Rahman MS, Amin SB, Chu R, Mamun HA (2019) Sources of trace elements identification in drinking water of Rangpur district Bangladesh and their potential health risk following multivariate techniques and Monte-Carlo simulation. Groundw Sustain Dev 9:100275. https://doi.org/10.1016/j. gsd.2019.100275

Islam ARMT, Islam HM et al (2020) Co-distribution, possible origins, status and potential health risk of trace elements in surface watersources from six major river basins Bangladesh. Chemosphere 249:126180. https://doi.org/10.1016/j.chemosphere.2020.126180

Jalali M (2006) Chemical characteristics of groundwater in parts of mountainous region, Alvand, Hamadan. Iran Environ Geol $51: 433-446$

Jalali M (2009) Phosphorous concentration, solubility and species in the groundwater in a semi-arid basin, southern Malayer, western Iran. Environ Geol 57:1011-1020

Jalali M (2011) Nitrate pollution of groundwater in Toyserkan, western Iran. Environ Earth Sci 62:907-913

Jennings D, Paul S, Diane D.W (1997) Nitrates in Drinkingwater. Washington State Department of Health (WSDOH). Anelectronic media retrieved from the website: http://www.doh.wa.gov/ehp/dw

Kabir MM, Sultana F, Rahman MM, Uddin MK (2020) Chromium (VI) removal efficacy from aqueous solution by modified tea wastespolyvinyl alcohol (TW-PVA) composite adsorbent. Desalination Water Treat 174:311-323

Kabir MM, Akter S, Ahmed FT, Mohinuzzaman M, Didar-ul-Alam M, Mostofa KMG, Islam ARMT, Niloy NM (2021) Salinity-inducedfluorescence dissolved organic matter influence co contamination, quality and risk to human health of tube well water insoutheastcoastal Bangladesh. Chemosphere 275:130053. https://doi.org/10. 1016/j.chemosphere.2021.130053

Kaçmaz H, Nakoman ME (2009) Hydrochemical characteristics of shallowgroundwater in aquifer containing uranyl phosphateminerals, in the Köprübaşı (Manisa) area. Turkey Environ Earth Sci 59:449-457. https://doi.org/10.1007/s12665-009-0043-3

Kaka EA, Akiti TT, Nartey VK, Bam EPK, Adomako D (2011) Hydrochemistryand evaluation of groundwater suitability for irrigationand drinking purposes in the southeastern Volta river basin:manya krobo area, Ghana. Elixir Agric 39:4793-4807

Karunanidhi D, Aravinthasamy P, Kumar D, Subramani T, Roy PD (2020) Sobol sensitivity approach for the appraisal of geomedical health risks associated with oralintake and dermal pathways of groundwater fluoride in a semi-arid region of south India. Ecotoxicol Environ Saf. https://doi.org/10.1016/j.ecoenv.2020.110438

Kelly WP (1976) Use of saline irrigation water. Soil Sci 95(4):355-391

Kong DY, Zhu ZL, Shi LL, Shan ZJ, Cai DJ (2004) Effectof pesticides on groundwater under sweet-potato-basedcropping systems in northern China. J Agro-Environ Sci 23:1017-1020

Kundu A, Nag SK (2018) Assessment of groundwater quality in kashipur block, purulia district, west Bengal. Appl Water Sci https://doi.org/10.1007/s13201-018-0675-0

Liu J, Peng Y, Li C, Gao Z, Chen S (2021) An investigation into the hydrochemistry, quality and risk to human health of groundwater in the central region of Shandong Province, North China. J Clean Prod. https://doi.org/10.1016/j.jclepro.2020.125416

IslamARMT MamunAA, RahmanMM ZahidA (2020) Simultaneous comparison of modified-integrated water quality and entropy weighted indices: implication for safe drinking water in the coastal region of Bangladesh. Ecol Indic 113:106229. https://doi.org/10. 1016/j.ecolind.2020.106229 
Mridul MMI, Huda ME, Khan M, Roy SK, Akter S, Kabir MM, Mouna SSP (2020) Groundwater quality and vulnerability assessment in Savar Dhaka Bangladesh. J Biol Environ Sci 17:1-9

Nagaraju A, Balaji E, Sun LH, Thejaswi A (2018) Processes controlling groundwater chemistry from Mulakalacheruvu area, Chittoor district, Andhra Pradesh, South India: a statistical approach based on hydrochemistry. J Geol Soc India 91:425-430

Nag SK, Das A (2017) Assessment of groundwater quality from bankura I and bankura II blocks, Bankura district, West Bengal, India. Appl Water Sci 7:3447-3467. https://doi.org/10.1007/ s13201-017-0530-8

Ahmed MN, Bodrud-Doza AR, Towfiqul Islam M, Shahadat Hossain M, Moniruzzaman ND, Abdul Quaiyum Bhuiyan M (2019) Appraising spatial variations of $\mathrm{As}, \mathrm{Fe}, \mathrm{Mn}$ and NO3 contaminations associated health risks of drinking water from Surma basin, Bangladesh. Chemosphere 218:726-740. https://doi.org/ 10.1016/j.chemosphere.2018.11.104

Ojekunle OZ, Ojekunle OV, Adeyemi AA, Taiwo AG, Sangowusi OR, Taiwo AM, Adekitan AA (2016) Evaluation of surface water quality indices and ecological risk assessment for heavy metals in scrap yard neighbourhood. Springerplus 5:560. https://doi.org/10. 1186/s40064-016-2158-9

Pritchard M, Mkandawire T, O'Neill JG (2008) Assessment of groundwater quality in shallow wells within the southern districts of Malawi. Phys Chem Earth 33:812-823

Raghunath HM (1987) Groundwater, 2nd edn. Wiley eastern limited, New Delhi, India, pp 344-369

Raji BA, Alagbe SA (1997) Hydrochemical facies in parts of the Nigerian basement complex. Environ Geol 29(1-2):46-49

Rasool A, Xiao T, Farooqi A, Shafeeque M, Liu Y, Kamran MA, Katsoyiannis IA, Eqani SAMA (2017) Quality of tube well water intended for irrigation and human consumption with special emphasis on arsenic contamination at the area of Punjab, Pakistan. Environ Geochem Health 39:847-863

Rezaei A, Hassani H, Hayati M, Jabbari N, Barzegar R (2017) Risk assessment and ranking of heavy metals concentration in Iran's Rayen groundwater basin using linear assignment method. Stoch Environ Res Risk Assess 32(5):1317-1336. https://doi.org/10. 1007/s00477-017-1477-x

Richards LA (1954) Diagnosis and improvement of saline and alkali soils; agric handbook, vol 60. USDA and IBH Publ. Coy Ltd., New Delhi, pp 98-99

Rikta SY, RahamanMS MJJ, UddinMK KabirMM, TareqSM ED (2016) Evaluation of water quality parameters and humic substance status of Bangshi Dhaleshwari and Padma Rivers in Bangladesh. Int J Environ Sci 6:1129-1139

Satish Kumar V, Amarender B, Dhakate R, Sankaran S, Raj Kumar K (2016) Assessment of groundwater quality for drinking and irrigation use in shallow hard rock aquifer of Pudunagaram, Palakkad District Kerala. Appl Water Sci 6:149-167

Shahid SU, Iqbal J, Hasnain J (2014) Groundwater quality assessment and its correlation with gastroenteritis using GIS: a case study of Rawal Town, Rawalpindi Pakistan. Environ Monit Assess 186:7525-7537. https://doi.org/10.1007/s10661-014-3945-9

Shaji E, Gomez A, Hussein S, Deepu TR, Anilkumar Y (2018) Salinization and deterioration of groundwater quality by nitrate and fluoride in the Chittur block, Palakkad, Kerala. J Geol Soc India 92:337-345

Sharma S, Nagpal A, Kaur I (2019) Appraisal of heavy metal contents in groundwater and associated health hazards posed to human population of Ropar wetland, Punjab, India and its environs. Chemosphere 227. https://doi.org/10.1016/j.chemosphere.2019.04.009

Simeonov V, Stratis JA, Samara C, Zachariadis G, Voutsa D, Anthemidis A, Sofoniuo M, Kouimtzis TH (2003) Assessment of the surface water quality in Northern Greece. Water Res 37:4119-4124
Singh AK, Mondal GC, Kumaar S, Sinngh TB, Sinha A (2008) Majorion chemistry, weathering processes and water quality assessment in upper catchment of Damodar River basin. India Environ Geol $54: 745-758$

Singh A, Srivastav SK, Kumar S, Chakrapani GJ (2015) A modified DRASTIC model (DRASTICA) for assessment of groundwater vulnerability to pollution in an urbanized environment in Lucknow. India Environ Earth Sci 74(7):5475-5490. https://doi.org/ 10.1007/s12665-015-4558-5

Singh AK, Sathya M, Verma S, Jayakumar S (2018) Health risk assessment of heavy metals in crop grains grown on open soils of Kanwar wetland India Euro-Mediterr. J Environ Integr 3:29. https:// doi.org/10.1007/s41207-018-0073-X

Subba Rao N, Sunitha B, Rambabu R, Nageswara PV, Surya Rao P, Deepthi Spandana B, Sravanthi M, Marghade D (2018) Quality and degree of pollution of groundwater, using PIG from a rural part of Telangana State. India Water Sci 8:227

Sultana F, Uddin MK, Kabir MM, Sultana N, Sikder MT, Rahman SM (2016) Removal efficiency of chromium (VI) ions from aqueoussolution by adsorption of rice husk and saw dust ash as a homogeneous composite. Int J Environ Sci 6:1129-1139

Taheri K, Gutie 'r rez F, Mohseni H, Raeisi E, Taheri M (2015) Sinkhole susceptibility mapping using the analytical hierarchy process (AHP) and magnitude-frequency relationships: a case study in Hamadan province. Iran Geomorphol 234:64-79. https://doi.org/ 10.1016/j.geomorph.2015.01.005

Tasneem A, Sarker P, Akter S, Mouna SSP, Rahaman MS, Mohinuzzaman M, UddinMK KMM (2021) Textile wastewater treatment by combination of chemical and phytoremediation processes. Pollution 7:43-54

Thapa R, Gupta S, Guin S, Kaur H (2017) Assessment of groundwater potential zones using Multi - Influencing factor( MIF) and GIS: a case study from Birbhum district, West Bengal. Appl Water Sci 7:4117-4131

Tiwari AK, Maio MD, Singh PK, Mahato MK (2015) Evaluation of surface water quality by using GIS and a heavy metal pollution index (HPI) model in a coal mining area. India Bull Environ Contam Toxicol 95:304-310

Todd DK (1980) Groundwater hydrology, 2nd edn. Wiley, New York, p 535

UNESCO (2007) UNESCO water portal newsletter no. 161. Waterrelated diseases. http://www.unesco.org/water/news/newsletter/ 161.shtml

USEPA (2011) Exposure Factors Handbook, 2011 edn.,. U.S. Environmental Protection Agency, https: //doi.org /EPA/600/R-090/052F

Vasanthavigar M, Srinivasamoorthy K, Vijayaragavan K, Ganthi RR, Chidambaram S, Anandhan P, Vasudevan S (2010) Application of water quality index for groundwater quality assessment: Thirumanimuttar sub-basin Tamilnadu, India. Environ Monit Assess 171:595-609

WHO (2011) WHO guidelines for drinking-water quality, 4th edn. World Health Organization, Geneva

Yang M, Fei Y, Ju YMZ, Li H (2012) Health risk assessment of groundwater pollution-a case study of typical city in north China. Plain J Earth Sci 23:335-348

Yao, X., Fu, B., Lü, Y., Sun, F., Wang, S., Liu, M. (2013) Comparison of FourSpatial Interpolation Methods for Estimating Soil Moisture in a ComplexTerrain Catchment. Schumann GJ-P. (Ed.), PLoS ONE. v.8(1), pp.e54660.DOI:https://doi.org/10.1371/journal. pone. 0054660

Publisher's Note Springer Nature remains neutral with regard to jurisdictional claims in published maps and institutional affiliations. 